\title{
URGENSI UNSUR ELIT DALAM PELAKSANAAN KEBIJAKAN INFORMASI PUBLIK DI JAWA BARAT
}

\author{
Diah Fatma Sjoraida, dan Rully Khairul Anwar \\ Fakultas Ilmu Komunikasi Universitas Padjadjaran, Jatinangor, Indonesia \\ E-mail: diah.fatma@unpad.ac.id,rully.khairul@unpad.ac.id
}

\begin{abstract}
ABSTRAK
Adanya Undang-undang Nomor 14/2008 tentang Keterbukaan Informasi Publik(KIP) secara tidak langsung telah mewajibkan pemerintah dan perangkat publik lainnnya untuk membuat informasi agar dapat diakses masyarakat. Juga berkewajiban memenuhi kebutuhan informasi yang dimohon oleh publik.Untuk menguatkan pelaksanaan tugas keterbukaan informasi dan pelayanan informasi publik, sebagai bukti komitmen dalam mematuhi UU KIP sekaligus mengarahkan seluruh jajaran aparat birokrasi, Pemerintah Provinsi Jabar menerbitkan Perda Nomor 11 Tahun 2011 tentang Transparansi, Partisipasi dan Akuntabilitas dalam Penyelenggaraan Pemerintahan Daerah Pemerintah Provinsi Jawa Barat untuk tujuan menyelenggarakan sistem pemerintahan yang baik, bersih, serta bebas dari KKN. Penelitian ini menggunakan metode deskriptif-kualitatif. Penelitian ini menemukan bahwa pelaksanaan kebijakan informasi publik di Jawa Barat masih banyak kekurangan, di antaranya adalah: mentalitas elit birokrasi; struktur dan wewenang organ pelaksana; multiintepretasi informasi publik; kebebasan dan kepercayaan masyarakat; sumber daya pendukung dan anggaran; dan pola layanan informasi publik.
\end{abstract}

Kata Kunci: Elite, birokrasi, kebijakan informasi publik,

\section{THE URGENCY OF ELITE IN IMPLEMENTING PUBLIC INFORMATION POLICY IN WEST JAVA}

\begin{abstract}
The existence of Law Number 14/2008 on Public Information Disclosure (KIP) has indirectly obliged the government and other public devices to make information accessible to the public. It is also obliged to meet the information requested by the public. To strengthen the implementation of the task of information disclosure and public information services, as a proof of commitment in complying with the Law on KIP as well as directing the whole range of bureaucratic apparatus, the Provincial Government of West Java issued the Regulation No. 11 of 2011 on Transparency, Participation and Accountability in Provision of Local Government West Java Provincial Government in organizing good and clean governance, and free from KKN. This research uses descriptive-qualitative method. This research found that the implementation of public information policy in West Java is still a lot of shortcomings, among them are: bureaucratic elite mentality; structure and authority of the implementing organs; multiinterpretation of public information; freedom and trust of the people; supporting resources and budget; and patterns of public information services.
\end{abstract}

Keywords: Elite, bureaucracy, implementation of public information

\section{PENDAHULUAN}

Terbitnya UU KIP (Undang-Undang Keterbukaan Informasi Publik) menjadi pintu masuk pemerintah dan perangkat publik lainnya untuk membuka akses informasi bagi masyarakat dengan cara mendirikan serta mengembangkan dokumentasi dengan sistem informasi secara aktif agar dapat diakses publik secara luas, cepat dan mudah dan juga pemerintah memiliki kewajiban untuk memenuhi kebutuhan informasi yang dimohon oleh publik. Domain hak informasi yang dapat diakses oleh publik, sebagaimana yang dijamin oleh UU KIP, adalah hak atas transparansi pengelolaan dana/sumber daya publik, hak atas informasi yang dikelola badan publik, dan hak atas informasi untuk mengetahui kinerja pejabat dalam menjalankan fungsi pemerintahan (Budhirianto, 2014:42).

Pelaksanaan UU KIP dapat berjalan baik, apabila birokrasi pemerintah baik di pusat ataupun di daerah mempunyai Pejabat Pengelola Informasi Daerah (selanjutnya disebut PPID) serta membentuk Komisi Informasi Daerah (KID). Untuk pemerintah 
Provinsi, Komisi Informasi yang dibentuk adalah Komisi Informasi Daerah (KID) Provinsi, sedangkan pada pemerintah kabupaten/ kota disebut Komisi Informasi Daerah (KID) Kabupaten/Kota.

Untuk menguatkan pelaksanaan tugas keterbukaan informasi dan pelayanan informasi publik, Pemerintah Provinsi Jabar juga menerbitkan Perda Nomor 11 Tahun 2011 tentang Transparansi, Partisipasi dan Akuntabilitas dalam Penyelenggaraan Pemerintahan Daerah. Penerbitan perda tersebut sebagai bukti komitmen Pemerintah Provinsi Jawa Barat dalam mematuhi UU KIP sekaligus mengarahkan seluruh jajaran aparat birokrasi di lingkungan Pemerintah Provinsi Jabar dalam menyelenggarakan pemerintahan yang baik dan bersih, serta bebas dari KKN.

Namun sejak diberlakukannya UU KIP tersebut, bukan berarti pelaksanaanya lancar. Banyak kendala yang dihadapi terkait pelaksanaan UU KIP ini. Meskipun Pemerintah Provinsi Jawa Barat sudah berusaha sebaik mungkin, namun tanggapan dari masyarakat mengenai pelaksanaan keterbukaan Informasi Publik masih belum sesuai harapan. Lembaga Swadaya Masyarakat Perkumpulan Inisiatif pernah mengatakan bahwa Pemprov Jabar sesungguhnya belum siap melaksanakan keterbukaan informasi publik. Statement ini dikeluarkan, setelah melaksanakan uji akses informasi publik yang ditujukan ke Organisasi Pemerintah Daerah (OPD) di lingkungan Pemerintah Provinsi Jawa Barat. Dari hasil uji tersebut, hanya sebagian kecil saja OPD yang memenuhi tuntutan kebutuhan informasi publik. Sebagian besar lagi memberikan tanggapan yang menyatakan menolak untuk memberikan informasi yang dibutuhkan publik tersebut (Republika, 27 Juni 2012).

Edward III telah mengajukan model 4 (empat) faktor keberhasilan implementasi kebijakan, namun Lewis dan Flynn (1978:5) berpendapat bahwasanya implementasi kebijakan itu sulit dilaksanakan secara efektif, karena dalam kenyataan akan selalu ada ketidaksetujuan mengenai tujuan dan sasaran kebijakan; kesamaran tentang kebijakan dan ketidakpastian dalam implentasinya; adanya aturan dalam pelaksanaan yang kompleks, dan perselisihan dari masyarakat yang berpartisipasi, adanya tekanan kelompok, serta perselisihan politik. Kemungkinan implementasi kebijakan terlaksana tidak efektif juga dinyatakan oleh Edwards III (1980: 2) mengatakan "meskipun kebijakan diambil secara tepat, namun kegagalan masih bisa terjadi jika proses implementasinya tidak tepat". Dengan kata lain sungguh pun kebijakan publik itu baik namun implementasinya buruk maka bisa mengalami kegagalan atau tidak efektif. Implementasi kebijakan yang tidak efektif menunjukkan aturan-aturan para pembuat keputusan tidak berjalan sesuai dengan harapannya (berhasilnya pencapaian tujuan). Hal ini berarti terdapat korelasi antara implementasi kebijakan dengan efektivitas, artinya implementasi kebijakan yang baik dan benar akan menghasilkan keberhasilan organisasi sehingga program dari kebijakan dapat terealisasi secara efektif. Dengan demikian, faktor-faktor sebagaimana yang telah ditampilkan dari pendapat Edwards III ini, memberi petunjuk bahwa faktor-faktor tersebut dapat memberikan pengaruh terhadap efektivitas implementasi kebijakan. Sebaliknya apabila faktor-faktor tersebut diatas mengalami kegagalan dalam pelaksanaannya maka dapat dipastikan kinerja dan target rencana organisasi dari implementasi kebijakan tidak akan tercapai (tidak efektif).

Dalam implementasinya, kebijakan publik bisa jadi disebabkan oleh banyaknya kepentingan-kepentingan politik yang bermain, saling mempengaruhi, dan berhubungan satu sama lain. Terkait adanya unsur kepentingan politik dalam implementasi kebijakan, Bardach (1977:56) membuat suatu analisis model permainan. Ia mengungkapkan bahwa implementasi adalah sebuah permainan "tawarmenawar", persuasi, dan manuver di dalam kondisi ketidakpastian. Model permainan sebagaimanadinyatakan Bardach, menunjukkan bahwa adanya unsur politis dalam implementasi kebijakan sebagai sesuatu yang melampaui institusi resmi. Oleh karena itu, implementasi merupakan bentuk lain dari politik yang berlangsung dalam domain kekuasaan, dimana politik tidak pernah berhenti dalam proses kebijakan, dimana ia selalu eksis bahkan ketika rancangan undang-undang sudah ditetapkan menjadi undang-undang. (Bardach, 1977)

Menurut Hoogerwerf, implementasi kebijakan mempunyai beberapa faktor yang dapat menjadi penghambat, di antaranya: 1) isi kebijakan yang tidak jelas, 2) ketiadaan informasi, 3) ketiadaan dukungan, 4) pembagian potensi (Bambang Sunggono, 1994:149-153). 
Selain keempat faktor di atas, kultur/ budaya juga mempengaruhi keberhasilan implementasi kebijakan. Charles Handy (dalam Parsons, 2008: 478-479) berpendapat bahwa ada empat tipe utama kultur yang dapat mempengaruhi keberhasilan suatu implementasi yaitu kekuasaan, peran, tugas, dan orang. Penjelasan dari keempat kultur utama tersebut, adalah sebagai berikut:

1) Kultur kekuasaan yaitu bagaimana sebuah jaringan dimana keputusan adalah hasil dari kekuasaan;

2) Kultur peran yaitu bagaimana rasionalitas yang dilaksanakan dari fungsi birokrasi;

3) Kultur tugas yaitu kultur yang berurusan dengan penyelesaian tugas. Kultur ini bersifat efisien dan adaptif jika menyesuaikan terhadap tuntutan konsumen (pemangku kepentingan);

4) Kultur orang yaitu serangkaian kultur dimana individu mendominasi struktur dan organisasi.

Kultur yang kuat dalam organisasi tidak selalu cocok dengan implementasi kebijakan karena adanya ketidaksesuaian dengan tujuan, tidak selalu cocok dengan orang-orang. Setiap kultur dapatmendorong implementasi kebijakan dengan baik dan efektif, tetapi bisa juga mengakibatkan ketidakefektifan dan kegagalan dalam implementasi kebijakan. Lebih lanjut, Charles Handy (dalam Parsons, 2008:479) mengatakan bahwa kultur dipengaruhi oleh sejarah, ukuran kebijakan, teknologi, tujuan dan sasaran, lingkungan dan orang. Mengenai aspek 'kultural' ini dapat disiasati melalui manajemen organisasi korporat, dimana keberhasilan implementasi kebijakan tergantung pada pentingnya pemahaman orang-orang dalam organisasi merespon tujuan yang diminta untuk mengimplementasikan kebijakan. Dua teknik yang dapat digunakan untuk meningkatkan aspek manusia dalam implementasi kebijakan yaitu melalui penilaian kinerja dan manajemen berbasis tujuan.

Penelitian ini akan berfokus pada urgensi elit dalam implementasi kebijakan publik mengenai informasi publik. Demikian karena kebijakan publik tidak ditentukan oleh "massa" melalui permintaan dan tindakan mereka tetapi kebijakan publik diputuskan oleh suatu elit yang mengatur dan dipengaruhi oleh instansi pejabat publik. Teori elit memusatkan perhatian pada tugas elit dalam pembentukan kebijakan dan pada kenyataannya bahwa dalam sistem politik orang yang memerintah jauh lebih sedikit dari pada orang yang diperintah (Keller, 1995).

Istilah elit menurut Keller, (1995:3) secara etimologis berasal dari kata eligere yang berarti memilih. Kata elit menunjuk suatu pilihan, pilihan suatu bangsa, budaya, kelompok usia, dan orang-orang yang menduduki posisi yang lebih tinggi. Dengan kata lain, elit adalah sekelompok kecil orang dalam masyarakat yang memegang posisi dan peranan penting. Aristoteles (dalam Chilcote, 2003) menjelaskan bahwaelitmerupakan sekelompokkecilindividu yang memangku hampir semua tanggungjawab kemasyarakatan. Pengertian elit yang diajukan Aristoteles menjadi penegasan lebih lanjut dari ungkapan Plato tentang demokrasi elitis klasik yang menjadi dalil inti teorinya bahwa dipadu setiap masyarakat, terdapat minoritas yang membuat ketentuan-ketentuan besar. Pareto (dalam Varma, 1987), menjelaskan bahwa setiap masyarakat yang diperintah oleh sekelompok kecil yang mempunyai kualitas yang diperlukan dalam kehidupan sosial dan politik. Kelompok kecil itu disebut dengan elit, yang mampu menjangkau pusat kekuasaan. Pareto membagi masyarakat dalam dua kelas. Pertama, lapisan atas, yaitu elit yang memerintah (governing elit) dan elit yang tidak memerintah (nongoverning elit). Kedua, lapisan lebih rendah (nonelit). Sementara itu, Gaetano Mosca menjelaskan, lapisan elit yang berkuasa dengan sebutan classe politica/political elit. Elit politik ini merupakan kelompok terorganisasi yang memiliki kewenangan politik. Kelas elit ini terdiri atas minoritas terorganisasi yang akan memaksakan kehendaknya melalui "manipulasi maupun kekerasan", khususnya dalam demokrasi. Elit politik juga menunjukkan semua fungsi politik, monopoli kekuasaan, dan menikmati setiap keuntungan dari kekuasaan. Kekuasaan yang mereka miliki tidak berasal dari komunitasnya atau posisi ekonomi, melainkan dari organisasinya yang berhubungan dengan kekuasaan publik Negara (Bellamy, 1990).

Berdasarkan kenyataan yang terjadi, pelaksanaan regulasi keterbukaan informasi publik (UU KIP) di Jawa Barat telah memunculkan konflik akibat adanya berbagai benturan kepentingan di lapangan. Terkait terjadinya konflik dalam implementasi UU KIP 
ini, penulis tertarik untukmengetahui bagaimana sesungguhnya proses pelaksanaan UU KIP oleh Pemerintah Provinsi Jawa Barat, serta untuk mengetahui faktor-faktor apa saja baik yang mendukung maupun menghambat keberhasilan implementasi UU KIP di Jawa Barat. Dengan mengetahui proses pelaksanaan UU KIP dan mengetahui faktor-faktor yang mempengaruhi keberhasilan UU KIP diharapkan dapat memberikan gambaran sesungguhnya kepada penulis (maupun seluruh pembaca) sehingga memberikan pemahaman akan kondisi dan permasalahan terkait pelaksanaan keterbukaan informasi publik di Jawa Barat.

\section{METODE}

Untuk mendapatkan informasi data baik data primer maupun sekunder terkait dengan penelitian ini digunakan teknik pengumpulan data melalui observasi, wawancara, dan teknik dokumentasi tentang objek penelitian yang meliputi tema, kebijakan, dan penyelenggaraan pelayanan informasi kepada publik Pemerintah Provinsi Jawa Barat.

Pengamatan langsung (participant observer) untuk mengumpulkan data dilakukan pada saat sebelumatau pada saatakan melakukan reduksi data. Peneliti berperan langsung dalam kondisi tertentu dan serta berpartisipasi aktif dalam kegiatan yang akan diteliti. Adapun objek yang diteliti antara lain implementasi aturan dan penyelenggaraan pelayanan informasi kepada publik yang meliputi komponen seperti SDM aparat pelaksana, sarana dan prasarana, perencanaan program dan kegiatan, struktur birokrasi, fungsi membangun koordinasi antar lembaga dan pelayanan informasi kepada publik.

Dalam wawancara, peneliti menggunakan menggunakan tiga jenis pendekatan wawancara secara kualitatif, yakni: 1) wawancara informal; 2) wawancara umum dan 3) wawancara terbuka. (Patton, 2002: 185). Dalam pelaksanaan wawancara, ketiga jenis pendekatan tersebut diselaraskan dengan topik yang akan dikaji dan sangat disesuaikan dengan kebutuhan pada saat wawancara dilakukan. Demi menjaga keabsahan data primer dari key informan, penelitia melakukan cek ulang data dengan informan pendukung, yaitu:

1) Seluruh komisioner pada Komisi Informasi Daerah (KID).
2) Pejabat Pengelola Informasi dan Dokumentasi (PPID).

3) Pejabat di lingkungan Setda Provinsi Jawa Barat dan beberapa OPD (OPD yang menjadi informan disesuaikan dengan kebutuhan informasi dan berdasarkan rumpun urusan pemerintahan seperti OPD rumpun pemerintahan, OPD rumpun Pelayanan Sosial Dasar, OPD rumpun pertanian, OPD rumpun ekonomi, OPD rumpun infrastruktur). Jumlah OPD yang diwawancarai dapat berkembang di lapangan sesuai kebutuhan data penelitian.

4) Aparat pelaksana pelayanan informasi publik (Diskominfo dan bagian Humas Setda Provinsi Bandung)

5) Informan pendukung: beberapa pemangku kepentingan (unsur masyarakat/LSM dan swasta)

Pengabsahan data dilakukan dengan dua cara, yaitu bersamaan hari setelah wawancara dengan informan, dan dengan waktu dan tempat yang berbeda menyesuaikan dengan keberadaan informan pendukung. Untuk data sekunder juga dilakukan verifikasi terhadap kebenaran informasi yang termuat dalam dokumen yang diperoleh.

\section{HASIL DAN PEMBAHASAN}

Berdasarkan hasil analisis proses yang telah dipaparkan di atas, terdapat faktor-faktor yang mempengaruhi pelaksanaan kebijakan keterbukaan informasi publik di Pemerintah Provinsi Jawa Barat berjalan tidak efektif adalah: mentalitas elit birokrasi; struktur dan wewenang organ pelaksana; multiintepretasi informasi publik; kebebasan dan kepercayaan masyarakat; sumber daya pendukung dan anggaran; dan pola layanan informasi publik.

\section{Mentalitas elit birokrasi}

Budaya kerja dan mentalitas SDM dalam pelaksanaan pelayanan informasi kepada publik dinilai masih lemah. Meskipun sudah beberapa kali dilaksanakan sosialisasi dan bimbingan teknis terkait pelaksanaan UU KIP, namun aparat badan publik belum mampu melaksanakannya dengan baik. Lemahnya mentalitas tersebut dilihat dari:

a. Lambannya badan publik di lingkungan Pemerintah Provinsi Jawa Barat yaitu 
OPD-OPD dalam melakukan update informasi yang wajib diumumkan pada di website jabarprov.go.id.

b. Lambannya atau keengganan merespon tuntutan permohonan informasi publik dari masyarakat (terutama informasiinformasi yang sensitif) disebabkan karena adanya budaya ketertutupan yang mengkhawatirkan informasi yang diakses oleh publik dapat mengungkapkan informasi rahasia negara yang tidak boleh diakses publik.

\section{Struktur dan wewenang}

PPID sebagai Organisasi Perangkat Daerah di lingkungan Pemerintah Provinsi Jawa Barat yang bertugas melayani permohonan informasi yang diminta masyarakat, wewenangnya hanya pada kegiatan OPD saja, tidak dijelaskan siapa atasan PPID, PPID utama, dan PPID pelaksana yang bertanggungjawab atas segala pelayanan informasi di jajaran provinsi. Ketidakjelasan struktur dan kewenangan ini menyulitkan Pemerintah Provinsi Jawa Barat dalam melakukan komunikasi dan koordinasi sehingga aliran informasi kepada publik tidak terkontrol dengan baik.

Selain itu bagi pelaksana pelayanan informasi publik tidak diberikan reward sebagaimana mestinya berupa perhitungan kinerja karena urusan informasi pelayanan publik oleh PPID masih dijadikan bukan fungsi utama yang masuk dalam tupoksi (tugas pokok dan fungsi) mereka, walaupun sebenarnya urusan layanan informasi publik ini sesungguhnya membutuhkan atensi serta konsentrasi lebih, juga memakan waktu, tenaga dan pikiran.

\section{Multiintepretasi informasi publik}

Masih adanya perdebatan antara pemerintah, masyarakat dan komisi informasi daerah (KID) Provinsi Jawa Barat terkait informasi publik yang dapat diakses secara terbuka dan informasi publik yang dikecualikan. Hal itu disebabkan oleh tidak adanya kebijakan pendukung khususnya mengenai mekanisme pelaksanaan uji informasi, consequency harm test dan public interest test, yang seharusnya dilakukan untuk membuat klasifikasi informasi tersebut. Tidak adanya klasifikasi dan daftar informasi mengundang multi intepretasi dan sulit tercapainya kesepakatan mengenai akses informasi publik.
Kebebasan Dan Kepercayaan Masyarakat

Demokrasi dan prinsip kebebasan sering disalahartikan oleh masyarakat yang tidak mau mematuhi ketentuan yang ada dalam aturan-aturan terkait hak akses pelayanan informasi publik. Aturan dan mekanisme dalam memperoleh informasi publik seringkali dianggap sebagai penghambat hak masyarakat dan menodai semangat keterbukaan informasi publik.

Tantangan lain yang dihadapi pemerintah dalam implementasi kebijakan keterbukaan informasi publik adalah persepsi masyarakat mengenai keseriusan Pemerintah Provinsi Jawa Barat dalam mewujudkan pemerintahan yang memegang prinsip transparansi dan akuntabilitas. Sampai saat ini, pelaksanaan kebijakan keterbukaan informasi publik di Provinsi Jawa Barat belum dapat mengubah persepsi masyarakat yang buruk terhadap kinerja pemerintah dan niat transparansi yang dilakukan pemerintah. Persepsi masyarakat yang buruk terhadap pemerintah atau poor public perception menurut Liu (dalam National Association of Government Communicators, 2008) adalah satu dari delapan tantangan dan peluang yang dihadapi pemerintah. Kurangnya kepercayaan publik menghalangi suksesnya pelaksanaan kebijakan keterbukaan informasi publik dan komunikasi antara pemerintah dengan masyarakat, yang mana masyarakat selalu mencurigai tindakan pemerintah termasuk mencurigai informasi yang disampaikan pemerintah. Untuk menghapus persepsi tersebut, pemerintah harus membuktikan komitmennya terhadap pelaksanaan kebijakan informasi publik dengan cara membuat kebijakan agar masyarakat dapat mengakses semua informasi yang selama ini dipegang pemerintah sesuai dengan ketentuan peraturan perundang-undangan yang berlaku.

\section{Sumber daya pendukung dan anggaran}

Anggaran di tiap-tiap OPD kurang mendukung karena tidak mengalokasikan secara khusus mengenai pelaksanaan urusan layanan informasi publik ini. Keterbatasan anggaran menyebabkan Pemerintah Provinsi Jawa Barat hanya mengandalkan sosialisasi eksternal melalui website Pemerintah Provinsi, namun tidak melakukan sosialisasi di media massa. Akibat sosialisasi penerapan informasi kepada masyarakat secara luas tidak berjalan sebagaimana mestinya. Tidak dianggarkannya 
urusan pelayanan informasi publik karena urusan ini masih dianggap urusan sampingan padahal seharusnya menjadi urusan utama yang dimasukkan ke dalam Tupoksi tiap-tiap OPD sehingga fungsi tersebut akan dilekatkan alokasi anggaran yang khusus terkait urusan PPID di tiap-tiap OPD. Oleh karena itu, perlu dilakukan revisi SOTK (Susunan Organisasi dan Tata Kerja) dengan memasukan fungsi PPID di tiap-tiap OPD. Sumber daya pendukung dan SDM dalam memanfaatkan teknologi dan informasi juga masih kurang, aparat yang melayani urusan informasi publik perlu difasilitasi.

\section{Pola layanan informasi publik}

Kesuksesan pelaksanaan kebijakan keterbukaan informasi publik di Provinsi Jawa Barat dalam mencapai tujuan mandat kebijakan sangat tergantung pada proses pelaksanaannya. Penerapan pola desentralisasi meskipun tidak salah, namun kurang efektif dalam pelaksanaan layanan informasi publik. Dengan pola ini standar layanan informasi publik di tiaptiap OPD menjadi tidak sama, serta sulitnya melakukan sinergi pelayanan informasi karena lemahnya komunikasi dan koordinasi di lingkungan Pemerintah Provinsi Jawa Barat terutama di antara OPD-OPD.

Dengan pola sentralisasi, Pemerintah Provinsi Jabar perlu segera membentuk PPID utama (atau PPID Provinsi) yang bertanggung jawab atas keseluruhan pelayanan informasi publik serta dapat memantau informasi pemerintah yang diakses masyarakat. Berdasarkan usulan beberapa OPD (dan hasil diskusi pada FGD yang dilakukan sebagai salah satu strategi memperoleh data pada penelitian ini) menghendaki pembentukan PPID utama (atau PPID Provinsi) sebagai panitia ad hoc yang di dalamnya terdapat unsur Sekretariat Daerah (Biro Humas), Bagian Hukum dan HAM, Diskominfo dan wakil-wakil OPD di bawah pimpinan Eselon II agar mempermudah koordinasi lintas OPD. Sekretariat PPID utama harus kuat dengan melibatkan secara aktif Dinas Komunikasi dan Informasi (Diskominfo) untuk mensosialisasikan, diseminasi informasi, pengelolaan website dan melakukan layanan dalam menyajikan informasi. Serta dkungan dari Biro Hukum dan HAM dalam melakukan menangani pengaduan dan sengketa informasi publik.
Pendirian panitia ad hoc ini juga disoking dengan Pergub yang mengatur tata cara pengelolaan dan pelayanan informasi publik sebagai panduan para pelaksana serta OPD dalam menyuguhkan layanan terbaiknya kepada masyarakat sebagai pemohon informasi, termasuk menyiapkan SOP hingga seleksi dan pemantauan pelayanan informasi publik.

Hal-hal yang dapat kita rangkum berdasarkan analisis proses dan faktor yang mempengaruhi pelaksanaan kebijakan keterbukaan informasi publik (KIP), adalah:

1. Interpretasi kebijakan KIP yang bersikap lebih hati-hati dalam membuka akses informasi yang luas kepada publik.

Meskipun ada jaminan kebebasan akses informasi namun untuk informasi tertentu (laporan keuangan) masih bersifat rahasia dan tidak perlu diketahui oleh publik. Masyarakat tidak mampu memahami bahasa laporan keuangan sehingga tidak kompeten untuk mengetahuinya. Di sini, faktornya adalah adanya mentalitas dan budaya ketertutupan bahwa kebebasan informasi dapat mengancam pemerintah. Budaya ketertutupan dipelihara untuk menjauhi upaya pengawasan masyarakat terhadap tindakan pemerintah.

Sebagai solusinya, Pemerintah Provinsi Jawa Barat harus mengubah mindset dan cultureset yang menjunjung tinggi prinsip keterbukaan dan akuntabilitas dengan memahami bahwa di era keterbukaan, informasi yang menyangkut kehidupan publik pada dasarnya terbuka untuk diakses dan diumumkan kepada publik.

Di sisi lain, lemahnya mutu pelayanan informasi publik karena organ pelaksana (PPID) tidak dibantu oleh pejabat fungsional pendukung (pranata komputer, humas dan arsiparis) yang melancarkan pelaksanaan tugasnya. Di sinilah terjadinya ketidakpahaman Pemerintah Provinsi Jawa Barat terhadap pembentukan PPID yang harus didukung oleh pejabat fungsional (Pasal 13 ayat 2).

Oleh karena itu, organ pelaksana (PPID) ke depan perlu dibantu oleh aparat fungsional yang menangani khusus urusan pelayanan informasi publik. Pejabat fungsional yang dimaksud adalah pranata komputer, humas dan arsiparis. 
2. Tidak ada kejelasan layanan informasi publik terkait pengkategorian informasi yang harus diumumkan setiap saat, informasi yang harus diumumkan berkala, serta informasi yang tidak boleh diakses oleh masyarakt (dikecualikan).

Masalahnya adalah belum adanya SOP yang memandu teknis pelayanan informasi publik di tiap-tiap OPD. Lemahnya pemanfaatan sistem informasi pada website untuk mengumumkan informasi kinerja dan pertanggungjawaban OPD. Penyelesaian sengketa tidak meminimalisasi gugatan masyarakat terhadap layanan informasi yang diberikan pemerintah Provinsi Jawa Barat, bahkan dengan konsekuensi sanksi pidana membuat badan publik (OPD) bersikap lebih hati-hati dan terkesan lebih tertutup dalam menanggapi permintaan informasi dari masyarakat.

Demikian pula, belum dirumuskannya daftar layanan informasi, klasifikasi informasi karena ketidakpahaman Pemerintah Provinsi Jawa Barat mengenai kriteria dan tatacara uji konsekuensi dan uji kepentingan publik dalam memformulasikan kategori dan daftar informasi tersebut. Belum adanya kesepakatan dan kesepahaman antara pemerintah, masyarakat dan komisi informasi mengenai informasi yang dikecualikan. Tidak adanya inisiatifOPD dalam menyusun SOP layanan informasi publik di OPD masing-masing tetapi malah menyerahkan tugas dan tanggung jawab tersebut kepada bagian hukum.

Penyelesaian sengketa mengancam konsekuensi sanksi pidana dan perdata terhadap semua kelalaian layanan informasi publik apabila masyarakat tidak puas terhadap putusan komisi informasi. Sebagai solusinya, Pemerintah Provinsi Jawa Barat perlu segera melakukan uji konsekuensi dan uji kepentingan publik untuk merumuskan klasifikasi dan daftar layanan publik. Peng-ujian dilakukan melibatkan unsur pemerintah (OPD), masyarakat, akademisi, praktisi, dan komisi informasi.

Sebelum melakukan pengujian tersebut perlu adanya kesepahaman dan kesepakatan semua elemen tentang kriteria informasi. Kepala Pemerintah Provinsi Jawa Barat melalui sekretaris daerah dengan power (kekuasaan) yang dimilikinya segera memerintahkan kepada seluruh OPD dalam lingkungan pemerintah Provinsi Jawa Barat untuk menyusun SOP layanan informasi publik yang disesuaikan dengan kondisi pada OPD masing-masing.

Pimpinan OPD memerintahkan dan mengawasi kerja aparat bawahannya untuk selalu melakukan pemuktahiran data dan informasi yang diumumkan ke website sesuai ketentuan Per-KI tentang SLPIP. Kewenangan komisi informasi perlu diperluas seperti komisi informasi di India dan Kanada yang memberikan kewenangan kepada komisi informasi sebagaimana kewenangan pengadilan untuk melakukan putusan yang sifatnya final dan mengikat.

Kelalaian aparat/maupun pejabat pemerintah terhadap layanan informasi publik bukan dianggap kejahatan yang berkonsekuensi pada hukum pidana. Kelalaian tugas cukup diberi sanksi administratif (penurunan pangkat dan jabatan ataupun skorsing) dan sanksi perdata (denda).

Sanksi pidana sebaiknya hanya diberlakukan bagi pelanggaran penghapusan, perubahan, dan/atau menghilangkan dengan sengaja informasi publik untuk kepentingan pribadi atau kelompok serta pemberian informasi yang menyesatkan secara sengaja sehingga berakibat pada kerugian seseorang. Perbuatan tersebut harus diberikan sanksi pidana karena jelas-jelas telah melanggar hak asasi warga negara terhadap akses informasi publik.

3. Rendahnya mutu kinerja pemerintah melemahkan kepercayaan masyrakat terhadap pemerintah.

Pemaksaan kehendak terhadap akses informasi publik serta citra pemerintah di media massa terlanjur menodai kepercayaan masyarakat. Hal ini ditambah dengan kurangnya sosialisasi pemerintah Provinsi Jawa Barat kepada masyarakat mengenai mekanisme dan tata cara permohonan informasi publik.

Di sinilah maka Pemerintah Provinsi Jawa Barat perlu membuktikan kepada masyarakat mengenai komitmennya terhadap keterbukaan informasi publik dan membuka dan mempermudah masyarakat untuk mengakses seluas mungkin informasi 
publik dengan tanpa melanggar ketentuan peraturan undang-undang yang berlaku. Untuk itu, pemerintah perlu melaksanakan sosialisasi secara intensif yang ditujukan kepada masyarakat terkait mekanisme dan tata cara permohonan informasi publik.

4. Perangkat TIK pada OPD tidak memadai, keterbatasan anggaran khusus alokasi layanan informasi publik, dan keterbatasan SDM aparat pelaksana.

Urusan pelayanan informasi publik merupakan fungsi sampingan dan bukan fungsi utama yang masuk dalam tupoksi OPD. Karena tidak termasuk tupoksi OPD, maka tidak ada alokasi anggaran khusus pelaksanaan urusan pelayanan informasi tersebut. Oleh karena itu diperlukan upayaupaya seperti melengkapi dan memperbaharui sarana dan prasarana TIK; merevisi SOTK OPD yang memasukkan fungsi $\mathrm{PPID}$ / pelayanan informasi ke dalam tupoksi menjadi salah satu fungsi utama OPD; dan peningkatan kapasitas pemahaman aparat terhadap pemanfaatan TIK.

5. Penerapan pola desentralisasi dalam layanan informasi ternyata kurang efektif, tidak adanya kewenangan dan pembentukan struktur yang jelas sehingga menyulitkan komunikasidan koordinasiantara pemerintah Provinsi Jawa Barat dengan OPD-OPD nya. Penerapan pola desentralisasi dengan tujuan memberikan pelayanan yang cepat, tepat dan mudah. Namun penerapan pola ini tidak disertai dengan kelengkapan organ pelaksana yang khusus menangani urusan pelayanan informasi publik sehingga pelayanan menjadi terhambat.

Perlu segera diupayakan penerapan pola sentralisasi dengan membentuk struktur PPID utama (PPID Provinsi), sekretaris PPID, dan PPID pembantu sehingga pelayanan informasi publik lebih tersistematis terkordinasi, dan sinergis antara pemerintah provinsi dengan OPD-OPD serta pemerintah Kabupaten/Kota di lingkungan Provinsi Jawa Barat.

Dari hasil penelitian ini ditemukan fakta yang dapat memberikan pemahaman kepada kita permasalahan yang dihadapi semua terkait kondisi implementasi UU KIP di
Jawa Barat. Beberapa fakta ditemukan bahwa implementasi UU KIP di lingkungan Pemerintah Provinsi Jawa Barat tidak sesuai dengan ketentuan peraturan perundangundangan dan tujuan dilaksanakannya kebijakan keterbukaan informasi publik.

\section{SIMPULAN}

Lambannya pemerintah Provinsi Jawa Barat dalam merespon permohonan layanan informasi publik atau tidak memperbaharui pengumuman informasi yang harus disediakan setiap saat oleh elit birokrasi menunjukkan lemahnya pemahaman dan kesadaran aparat dan pejabat pelaksana (PPID) di Lingkungan Pemerintah Provinsi Jawa Barat terhadap substansi, asas dan tujuan UU KIP bahwa informasi pada dasarnya bersifat terbuka dan dapat diakses masyarakat. Pelaksanaan UU KIP dengan pola desentralisasi, justru melemahkan fungsi organisasi pelaksana. Pelaksanaan tugas PPID di OPD masing-masing berjalan sendirisendiri. Tidak adanya integrasi dan koordinasi terkait pelaksanaan teknis UU KIP di seluruh OPD. Pelaksanaan pelayanan informasi publik tidak seragam dan tidak adanya pejabat yang lebih tinggi untuk bertanggung jawab atas seluruh layanan informasi yang diberikan di lingkungan Pemerintah Provinsi Jawa Barat. Ketentuan pada UU KIP menghendaki struktur organisasi pelaksana terdiri dari PPID (yang dibantu pejabat fungsional) dan atasan PPID. Meskipun Pemerintah Provinsi Jawa Barat sudah memiliki sistem dan jaringan informasi yang menghubungkan tiap-tiap OPD, namun tidak semua OPD memperbaharui informasi seperti informasi kinerja OPD yang dapat diakses masyarakat di link website resmi Pemerintah Provinsi Jabar. Setiap permohonan layanan informasi yang dikirimkan Diskominfo ke link email OPD, tidak cepat ditindaklanjuti. Padahal dengan membangun sistem informasi, pelayanan informasi publik dapat terselenggara lebih cepat dan murah. Belum adanya Standar Operasional Prosedur (SOP) dalam layanan informasi publik di masing-masing OPD, tidak memberikan jaminan kepada masyarakat mengenai kepastian waktu dan proses layanan informasi publik. Di sinilah pentingnya elit birokrasi yang kuat, sehingga dapat memberikan layanan terbaik untuk masyarakat. 


\section{DAFTAR PUSTAKA}

Bardach, E. (1977). The Implementation Game. Cambridge, Mass: MIT Press.

Bellamy, Richard. (1990). Teori Sosial Modern: Perspektif Italia. Penerjemah Vedi R. Hadiz. Jakarta: LP3ES.

Budhirianto, Syarif. (2014). PPID dan Transfer Informasi dalam Perspektif Keterbukaan Informasi Publik di Jawa Barat. Jurnal Observasi, Vol. 12, No.1.

Chilcote, Ronald H. (2003). Teori Perbandingan Politik: Penelusuran Paradigma. Jakarta: Raja Grafindo Persada.

Edwards III. (1980) Implementing Public Policy. Washington DC: Congressional Quarterly Press.

Grindle, M. S. (ed). 1980. Politics and Policy Implementation in the Third World. Princeton: Princeton University Press.

Keban, Y. T.( 2008). Administrasi Negara. Yogayakarta: Gava Media.

Keller, Suzanne. (1995). Penguasa dan kelompok Elite: Peranan Elite dalam Msyarakat Modern. Terjemahan. Jakarta: Rajawali Press.
Lewis, J. and R. Flynn. (1978). The Implementation of Urban and Regional Planning Policies: Final Report of $A$ Feasibility Study for Department of The Environment, London: Oxford University Press.

Meter, Van \& Horn, Van. (1974). Human Resource Champions. Boston: Harvard Business School Press.

Parsons, W. (2008). Public Policy: Pengantar Teori dan Praktik Analisis Kebijakan, Jakarta: Penerbit Kencana.

Patton, M. Q. (2002), Qualitative Research and Evaluation Methods. 3rd edition, London: Sage Publications, (1990).

Sunggono, B. (1994). Hukum dan Kebijaksanaan Publik. Jakarta: Sinar. Grafika.

Varma, S.P. (1987). Teori Politik Modern. Jakarta: Rajawali Pers.

Williams, W. (1971). Studying Implementation. Chatham, N.J.: Chatham House. 